\title{
Clear cell adenocarcinoma of bladder expressing prostate-specific antigen, alpha-methylacyl-CoA racemase and $\mathrm{CD10}$
}

\author{
Tadashi Terada* \\ Departments of Pathology, Shizuoka City Shimizu Hospital, Shizuoka, Japan
}

Received: February 28, 2016

Accepted: March 25, 2016

Online Published: April 6, 2016

DOI: $10.5430 /$ crcp.v3n4p1

URL: http://dx.doi.org/10.5430/crcp.v3n4p1

\begin{abstract}
Backgrounds: Clear cell adenocarcinoma (CCA) of urinary bladder (UB) is rare.

Aims: To report a case of CCA of UB immunohistochemically expressing prostate-specific antigen (PSA), alpha-methylacyl-CoA racemase (AMACR) and $\mathrm{CD} 10$; thus this case was difficult to differentiate from metastasis from prostatic adenocarcinoma or renal cell carcinoma (RCC).

Case: An 84-year-old man presented with dysuria and hematuria, and cystoscopy revealed a bladder tumor. The biopsy showed proliferation and invasion (more than pT2) of high-grade carcinoma cells focally forming glandular structures. Lymphovascular permeations were recognized. Focally, usual urothelial carcinoma (UC) was seen and there were gradual direct transitions between the clear cell carcinoma and UC. Immunohistochemically, the carcinoma cells were positive for PSA, AMACR, CD10, p53, Ki67 (labeling $=10 \%$ ), uroplakin II, thrombomodulin, and cytokeratin $(\mathrm{CK})$ 20, but negative for Hepatocyte-paraffin1 (HepPar1), CK7, PAX8, and TTF-1.

Conclusions: A rare case of CCA of UB with immunoexpressions of PSA, AMACR and CD10 is reported. The aberrant expressions of these three antigens are only speculative. The gradual transitions between UC and CCA and the presence of urothelial antigens in this tumor suggest that the tumor might have originated from UC.
\end{abstract}

Key Words: Urinary bladder, Clear cell adenocarcinoma, Prostate-specific antigen, Alpha-methylacyl-CoA racemase, CD10

\section{INTRODUCTION}

Carcinoma of the urinary bladder (UB) is common and characterized by frequent multicentricity and high rate of recurrence. Most of UB carcinoma is urothelial carcinoma (UC) of various grade, followed in order by ordinary adenocarcinoma and squamous cell carcinoma. Clear cell adenocarcinoma (CCA) of UB, first coined by Young and Scully ${ }^{[1,2]}$ is rare; to the author' knowledge, 29 case reports or case series have been reported. ${ }^{[1-29]}$ It can be present in focal foci in other types of bladder carcinomas. CCA of UB is different from much more common clear cell carcinoma which is defined as carcinoma having hobnail cells and glycogen-rich clear cells. High specificity and high sensitivity are most important in immunohistochemical studies. Various tumorspecific proteins with high sensitivity and high specificity were discovered in recent years. For example, TTF-1 is specific for thyroidal and lung alveolar epithelium and their tumors, CDX-2 for gastrointestinal and pancreatobiliary ep-

\footnotetext{
*Correspondence: Tadashi Terada; Email: piyo0111jp@yahoo.co.jp; Address: Department of Pathology, Shizuoka City Shimizu Hospital, Miyakami 1231 Shimizu-Ku, Shizuoka 424-8636, Japan. 
ithelium and their neoplastic counterparts, surfactant apoprotein A (SA) for pulmonary alveolar epithelium and its tumors, prostate-specific antigen (PSA) for prostatic glands and their tumors, alpha-methylacyl-CoA racemase (AMACR) for prostatic adenocarcinoma, CD10 for renal cell carcinoma (RCC) and B-cell lymphoma and Hepatocyte-paraffin1 (HepPar1) for hepatocytes and hepatocellular carcinoma (HCC), and so many proteins. These so called "specific" antigens or proteins have been used to determine cell types or even malignant potentials for many tumors. Only a little is known about immunoexpression in CCA of UB, while ordinary urothelial carcinomas of UB are known to express EMA, high-molecular-weight cytokeratins, p63, p40, thrombomodulin, uroplakin II, invulcurin, and other molecules. The author herein reports a case of CCA of UB expressing PSA, AMACR and CD10.

\section{CASE REPORT}

An 84-year-old man presented with dysuria and hematuria. The patient received cystoscopy which revealed a polypoid bladder tumor measuring circa $3 \mathrm{~cm} \times 3 \mathrm{~cm}$ at the triangle. Digital rectal examination of prostate was normal and serum PSA level was normal $(3.8 \mathrm{ng} / \mathrm{ml})$. Radiologic imaging studies showed the UB tumor, but no other tumors in the body including kidney, ureter and renal pelvis. Many biopsies were taken from the UB tumor, like transurethral resection of bladder tumor (TUR-BT), and they showed proliferation and invasion (positive muscular invasion, $\mathrm{pT} 2$ or more) of high-grade (Grade 3) carcinoma cells with very clear cytoplasmas (see Figure 1A-B). Glandular structures were focally noted (see Figure 1A-C). Lymphovascular permeations were evident. Focally, usual UC of Grade 2 was seen in the surface and there were gradual direct transitions between the clear cell carcinoma and UC (see Figure 1C).

A histochemical stains using periodic acid-Schiff after diastase digestion (d-PAS), mucicarmine and alcian blue at $\mathrm{pH} 2.5$ showed a little mucin in the tumor cell cytoplasmas. No significant glycogen was seen in the tumor cell cytoplasmas by PAS and d-PAS stainings. Fat stains using formalin-fixed tissue revealed no fat. An Immunohistochemical (IHC) study was carried out with the use of Envision method. In the much dominant adenocarcinoma areas, it was as follows: PSA + (see Figure 1D), AMACR + (see Figure 1E), CD10 ++ (see Figure 1F), Uroplakin II + (see Figure 1G), thrombomodulin +, p53 ++ (see Figure 1H), Ki67 (labeling $=20 \%$ ) cytokeratin (CK) $20+++$, CKAE1/3 ++, CKCAM5.2 +, CK34BE12 +. CK5 +, CK6 +, CK14 -, CK18 +, p63 -, HepPar1 -, CK7 -, CDX-2 -, PAX 8 -, RCC marker -, and TTF-1 -. In the very tiny UC areas, it was as follows: PSA -, AMACR -, CD10 -, Uroplakin II +, thrombomodulin +, p53 -, Ki67 (labeling $=4 \%$ ) cytokeratin $(\mathrm{CK}) 20+$, CKAE1/3 + , CKCAM5.2 -, CK34BE12 +. CK5 +, CK6 +, CK14 -, CK18 -, p63 -, HepPar1 -, CK7 -, CDX-2 -, PAX 8 -, RCC marker -, and TTF-1 -.

The patient is now treated by chemotherapy (cisplatin-based), focal radiation (40Gy) without operation because of his high age. No obvious tumor reduction was recognized. The patient is still alive with the bladder tumor 5 months after the histological diagnosis.

\section{Discussion}

CCA of UB should be differentiated from much more common clear cell carcinoma which is characterized by glycogenrich clear cells and hobnail cells. A review of CCA of UB in English literature showed 42 cases (SE) with mean age of 54 years (9 years) and with female predominance (M:F=12:29). ${ }^{[1-29]}$ Most patient presented with hematuria or dysuria. The treatment was variable, because no clinical tests of this tumor for treatments are available; it was almost the same as treatments of ordinary UC (endoscopic, operation, irradiation and anti-cancer drugs). The most interesting was the histogenesis of this tumor; this tumor seems to be heterogenous. Suspected origins are Mullerian ducts, endometriosis, and nephrogenic metaplasia. ${ }^{[1-29]}$ In the present study, the CCA was histologically in contact with UC cells and immunohistochemically expressed urothelial antigens (thrombomodulin and uroplakin II), suggesting that the present CCA of bladder developed from UC. The present case is male patient; therefore the former two hypotheses are unlikely. The author thought that the present CCA of UB have arose frpm preexisting UC of UB.

The present UB tumor is apparently a carcinoma. The present tumor is not usual UC. The present tumor is highly likely to be adenocarcinoma because of the presence of focal gland formations and mucin. ${ }^{[1-3]}$ However, the histology resembles RCC, HCC, prostatic adenocarcinoma, and clear cell malignancies of other primary sites. The present case is apparently different from papillary urothelial neoplasma and inverted papilloma. The tumor somewhat resemble nephrogenic adenoma but is different from it because of positive malignant features. The tumor should be differentiated from urachal carcinoma, but it usually shows colonic-type adenocarcinoma and most often arise from tip of bladder.

Therefore IHC investigation was performed, and it showed positive reactions to PSA, AMACR, and CD10. In general, AMACR is known to be relatively specific to prostatic adenocarcinoma, but it is shown that non-prostatic carcinomas infrequently are positive for AMACR, a pitfall of diagnostic pathology of prostatic carcinoma. CD10 is relatively spe- 
cific for B-cell neoplasma, myoepithelial cells, mesenchymal cells, in addition to RCC. The present case shows that CCA of UB can have positive immunoproducts of PSA, AMACR and CD10. The problem in this case is positive for PSA immunoreaction. PSA is now though to be highly specific for prostatic gland and its malignant counterparts. However, ectopic production of PSA by non-prostatic tissues has been reported. ${ }^{[30,31]}$ Ectopic prostate is also reported. In Dennis report, ${ }^{[32]}$ the sensitivity and specificity of PSA for prostatic adenocarcinoma is $100 \%$ and $99 \%$, respectively. However, it was shown that PSA is expressed in vast kinds of carcinomas. From these findings, it is highly conceivable that the present tumor is primary CCA of UB ectopically producing PSA,
AMACR and CD10. Positive expression of AMACR in CCA of UB was reported only once, ${ }^{[14]}$ and positive expression of CD10 may support the nephrogenic origin of the current tumor. The possibility that the present tumor is UB extension from occult prostatic adenocarcinoma is still remains now. The findings that the present tumor cells showed mucins and the observation that the present CCA cells are in continuity with overlying UC component, are strongly suggestive that the present tumor is primary CCA of UB. It is quite unlikely that the present tumor is metastatic RCC. The clinical and histological features of the present tumor are also not compatible with prostatic adenocarcinoma, but are consistent with primary UB carcinoma.

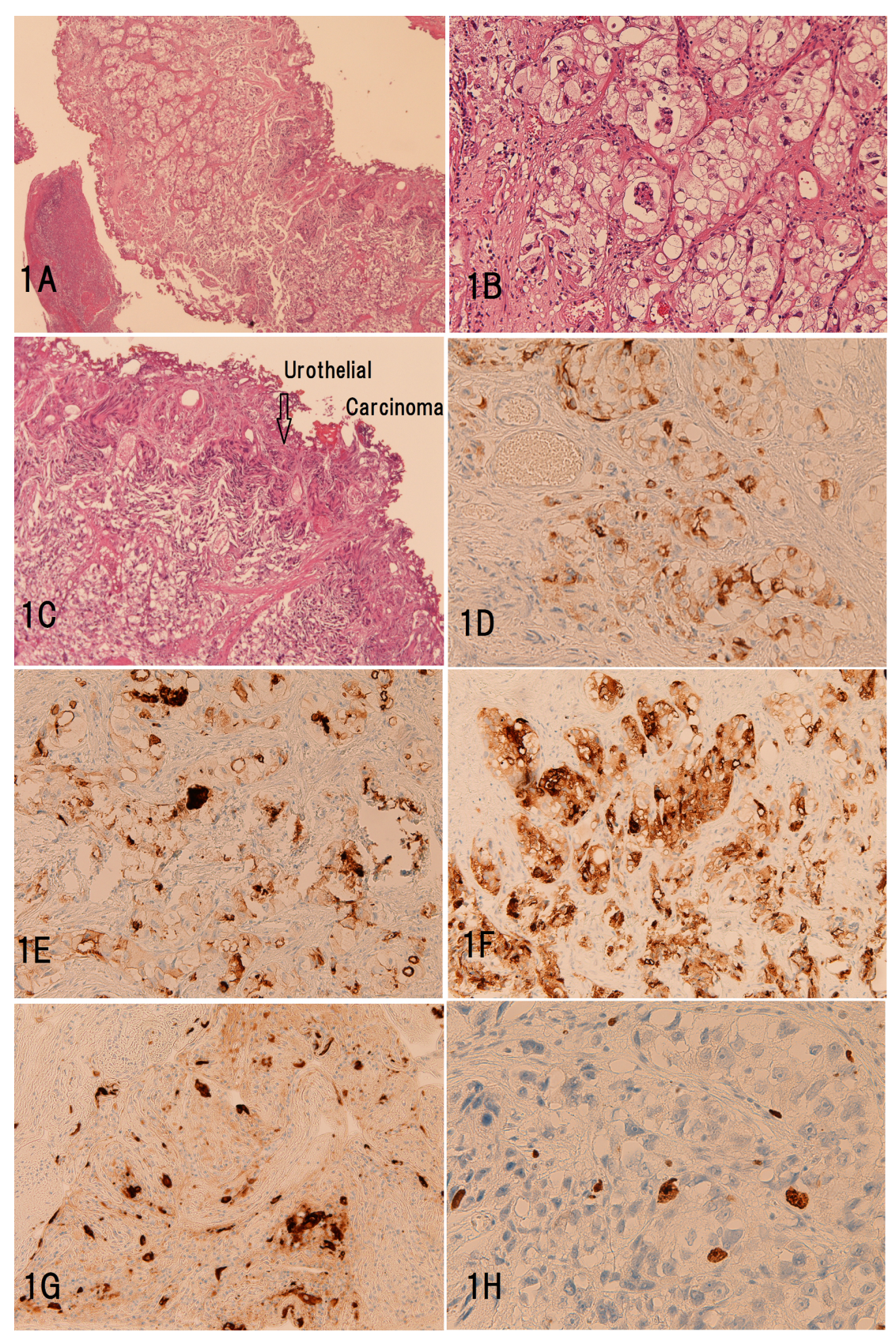

Figure 1. Histological (A-C) and Immunohistochemical (D-H) features of the bladder tumor

A: The biopsies shows proliferation and invasion of high-grade carcinoma cells with clear cytoplasms. $H E, \times 20$. B: High power view. The tumor cells had high grade atypia and very clear cytoplasms. Tubular formations are seen in focal areas. HE, $\times 200 . C$ : This field shows ordinary urothelial carcinoma (upper right) and the clear cell carcinoma cells (lower) with gradual merges between the two. HE, $\times 100$. D-F: Immunohistochemistry. The tumor cells are positive for PSA $(D)$, AMACR $(E), C D 10(F)$, uroplakin II $(G)$ and p53 (H). D-G: $\times 100$. $H: \times 300$. 


\section{Conclusions}

A rare case of primary CCA of UB with immunoexpressions of PAS, AMACR, and CD10 was reported. The carcinoma appeared to originate from ordinary UC.

\section{CONFLicts OF InTEREST Disclosure}

The author declares no conflict of interest.

\section{REFERENCES}

[1] Young RH, Scully RE. Nephrogenic adenoma. A report of 15 cases, review of the literature, and comparison with clear cell adenocarcinoma of the urinary tract. Am J Surg Pathol. 1986; 10: 268-75. PMid: 3706613. http://dx.doi .org/10.1097/00000478-198 604000-00005

[2] Young RH, Scully RE. Clear cell adenocarcinoma of the bladder and urethra. A report of three cases and review of the literature. Am J Surg Pathol. 1985; 1: 816-26. http://dx.doi.org/10.1097/0 0000478-198511000-00005

[3] Marchalik D, Krishnan J, Verghese M, et al. Clear cell adenocarcinoma of the bladder with intravesical cervical invasion. BMJ Case Rep. 2015; 24: 2015. pii: bcr2015209893. http://dx.doi.org/1 $0.1136 /$ bcr-2015-209893

[4] Loizzi V, Cormio G, Leone L, et al. A rare case of primary clear-cell adenocarcinoma of the bladder arising from bladder endometriosis. J Obstet Gynaecol. 2015; 35(7): 758-60. PMid: 25642923. http://dx.doi.org/10.3109/01443615.2015.1004526

[5] Terada T. An autopsy case of clear cell adenocarcinoma of the urinary bladder. Appl Immunohistochem Mol Morphol. 2013; 21: 371-5 PMid: 22024991. http://dx.doi.org/10.1097/PAI.0b013e3 $1821 \mathrm{~b} 193 \mathrm{~b}$

[6] Dhaliwal CA, Fineron PW. The progression of nephrogenic metaplasia of the urinary bladder to clear cell adenocarcinoma: a case report. Curr Urol. 2012; 6: 106-8. PMid: 24917724. http://dx. doi .org $/ 10.1159 / 000343520$

[7] Whitworth SA, Subhawong AP, Rosenthal DL, et al. Clear cell adenocarcinoma of the lower urinary tract: cytopathologic characteristics and differential diagnoses. Cancer Cytopathol. 2012; 120: 308-12. PMid: 22517612. http://dx.doi.org/10.1002/cncy.21197

[8] Lu J, Xu Z, Jiang F, et al. Primary clear cell adenocarcinoma of the bladder with recurrence: a case report and literature review. World J Surg Oncol. 2012; 10: 33. PMid: 22325372. http: $/ / \mathrm{dx}$.doi.org/10.1186/1477-7819-10-33

[9] Sethi S, Dhawan S, Chopra P. Clear cell adenocarcinoma of urinary bladder: A case report and review. Urol Ann. 2011; 3: 151-4. PMid: 21976929. http://dx.doi.org/10.4103/0974-7796.84962

[10] Brimo F, Herawi M, Sharma R, et al. Hepatocyte nuclear factor- $1 \beta$ expression in clear cell adenocarcinomas of the bladder and urethra: diagnostic utility and implications for histogenesis. Hum Pathol. 2011; 42: 1613-9. PMid: 21496868. http://dx.doi.org/10.10 16/j.humpath.2011.01.007

[11] Herawi M, Drew PA, Pan CC, et al. Clear cell adenocarcinoma of the bladder and urethra: cases diffusely mimicking nephrogenic adenoma. Hum Pathol. 2010; 41: 594-601. PMid: 20060152. http://dx.doi.org/10.1016/j.humpath.2009.10.011

[12] Adeniran AJ, Tamboli P. Clear cell adenocarcinoma of the urinary bladder: a short review. Arch Pathol Lab Med. 2009; 133: 987-91. PMid: 19492895.

[13] Bagby CM, MacLennan GT. Clear cell adenocarcinoma of the bladder and urethra. J Urol. 2008; 180: 2656. PMid: 18951583 http://dx.doi.org/10.1016/j.juro.2008.09.064
[14] Sun K, Huan Y, Unger PD. Clear cell adenocarcinoma of urinary bladder and urethra: another urinary tract lesion immunoreactive for P504S. Arch Pathol Lab Med. 2008; 132: 1417-22. PMid: 18788852.

[15] Adams B, Sawhney R, Sheil A, et al. A rare case of clear cell adenocarcinoma of the bladder with unique pathological features. Am J Med Sci. 2007; 333: 63-5. PMid: 17220697. http://dx.doi.org /10.1097/00000441-200701000-00010

[16] Hartmann A, Junker K, Dietmaier W, et al. Molecular evidence for progression of nephrogenic metaplasia of the urinary bladder to clear cell adenocarcinoma. Hum Pathol. 2006; 37: 117-20. PMid: 16360424. http://dx.doi.org/10.1016/j.humpath.2 005.09 .013

[17] Kurosaka S, Irie A, Mizoguchi H, et al. Advanced clear-cell adenocarcinoma of the bladder successfully treated by radical surgery with adjuvant chemoradiotherapy. Int J Clin Oncol. 2005; 10: 3625. PMid: 16247666. http://dx.doi.org/10.1007/s10147-0 05-0497-6

[18] Kösem M, Sengül E. Clear cell adenocarcinoma of the urinary bladder. Scand J Urol Nephrol. 2005; 39: 89-92. PMid: 15764280. http://dx.doi.org/10.1080/00365590510007630

[19] Signori G, Tonini G, Aulenti V, et al. Clear cell adenocarcinoma of the bladder in a male patient: clinicopathologic analysis of a case. Urol Int. 2003; 71: 228-30. PMid: 12890970. http://dx.doi.org $/ 10.1159 / 000071856$

[20] Moinzadeh A, Latini J, Hamawy KJ. Clear cell adenocarcinoma of the urinary bladder within a diverticulum. Urology. 2003; 62: 145. http://dx.doi.org/10.1016/S0090-4295(03) 00242-5

[21] Matsuoka Y, Machida T, Oka K, et al. Clear cell adenocarcinoma of the urinary bladder inducing acute renal failure. Int J Urol. 2002; 9: 467-9. PMid: 12225345. http://dx.doi.org/10.1046/j.1 $442-2042.2002 .00496 . x$

[22] Mai KT, Yazdi HM, Perkins DG, et al. Multicentric clear cell adenocarcinoma in the urinary bladder and the urethral diverticulum: evidence of origin of clear cell adenocarcinoma of the female lower urinary tract from Müllerian duct remnants. Histopathology. 2000; 36: 380-2. PMid: 10841652. http://dx.doi.org/10.1046/j.1 365-2559.2000.0855e.x

[23] Gilcrease MZ, Delgado R, Vuitch F, et al. Clear cell adenocarcinoma and nephrogenic adenoma of the urethra and urinary bladder: a histopathologic and immunohistochemical comparison. Hum Pathol. 1998; 29: 1451-6. http://dx.doi.org/10.1016/S0046 -8177 (98) 90015-6

[24] Ceccherini AF, Leach IH, Green D. Clear cell adenocarcinoma affecting the bladder, kidney and ureter-an unusual distribution. Br J Urol. 1997; 79: 652-3. PMid: 9126105. http://dx.doi .org/10. 1046/j.1464-410X.1997.00164.x

[25] Drew PA, Murphy WM, Civantos F, et al. The histogenesis of clear cell adenocarcinoma of the lower urinary tract. Case series and review of the literature. Hum Pathol. 1996; 27: 248-52. http://dx.doi.org/10.1016/S0046-8177 (96) 90064-7

[26] Balat O, Kudelka AP, Edwards CL, et al. Malignant transformation in endometriosis of the urinary bladder: case report of clear 
cell adenocarcinoma. Eur J Gynaecol Oncol. 1996; 17: 13-6. PMid: 8750509.

[27] Alsanjari N, Lynch MJ, Fisher C, et al. Vesical clear cell adenocarcinoma. V. Nephrogenic adenoma: a diagnostic problem. Histopathology. 1995; 27: 43-9. PMid: 7557905. http://dx.doi .org/10.11 11/j.1365-2559.1995.tb00289.x

[28] Chor PJ, Gaum LD, Young RH. Clear cell adenocarcinoma of the urinary bladder: report of a case of probable müllerian origin. Mod Pathol. 1993; 6: 225-8. PMid: 8483895.

[29] Abenoza P, Manivel C, Fraley EE. Primary adenocarcinoma of urinary bladder. Clinicopathologic study of 16 cases. Urology. 1987; 29: 9-14. http://dx.doi.org/10.1016/0090-4295(87) 90588-7
[30] Wu JT, Zhang P, Astill ME, et al. PSA immunoreactivity detected in LNCaP cell medium, breast tumor cytosol, and female serum. J Clin Lab Anal. 1995; 9: 243-51. http://dx.doi.org/10.1002/jcla. 1860090406

[31] Yu H, Diamandis EP, Levesque M, et al. Ectopic production of prostate specific antigen by a breast tumor metastatic to the ovary. $\mathrm{J}$ Clin Lab Anal. 1994; 8: 251-3. PMid: 7523638. http://dx.doi.o $\mathrm{rg} / 10.1002 / \mathrm{jcla} .1860080412$

[32] Dennis JL, Hvidsten TR, Wit EC, et al. Markers of adenocarcinoma characteristic of the site of origin: development of a diagnostic algorithm. Clin Cancer Res. 2005; 11: 3766-72. PMid: 15897574 http://dx.doi.org/10.1158/1078-0432.CCR-04-2236 